\title{
Effects of Lithium on Electrical Activity and Potassium Ion Distribution in the Vertebrate Central Nervous System
}

\author{
P. GRAFE, M. M. REDDY, H. EMMERT and G. TEN BRUGGENCATE \\ Physiologisches Institut der Universität München, Pettenkoferstr. 12, D-8000 München 2 (F.R.G.)
}

(Accepted March 22nd, 1983)

Key words: lithium - motoneurons - glial cells — spinal cord - cortex — hippocampus — potassium

\begin{abstract}
Three different regions of the vertebrate central nervous system maintained in vitro (frog spinal cord, guinea pig olfactory cortex and hippocampus) have been used to investigate how $\mathrm{Li}^{+}$influences membrane potential, membrane resistance, action potentials, synaptic potentials and the transmembrane $\mathrm{K}^{+}$-distribution of neurons and glial cells. In view of the therapeutic action of $\mathrm{Li}^{+}$in manicdepressive disease, a special effort was made to determine the threshold concentration for the actions of $\mathrm{Li}^{+}$on the parameters described above. It was observed that $\mathrm{Li}^{+}$induced a membrane depolarization of both neurons and glial cells, a decrease of action potential amplitudes, a facilitation of monosynaptic excitatory postsynaptic potentials and a depression of polysynaptic reflexes. The membrane resistance of neurons was not altered. $\mathrm{Li}^{+}$also induced an elevation of the free extracellular potassium concentration and a decrease of the free intracellular potassium concentration. Furthermore, in the presence of $\mathrm{Li}^{+}$a slowing of the recovery of the membrane potential of neurons and glial cells, and of the extracellular potassium concentration after repetitive synaptic stimulation was observed. The threshold concentrations for the effects of $\mathrm{Li}^{+}$were below $5 \mathrm{mmol} / \mathrm{l}$ in the frog spinal cord and below $2 \mathrm{mmol} / 1$ in the guinea pig olfactory cortex and hippocampus. The basic mechanism underlying the action of $\mathrm{Li}^{+}$may be an interaction with the transport-function of the $\mathrm{Na}^{+} / \mathrm{K}^{+}$pump.
\end{abstract}

\section{INTRODUCTION}

Despite extensive investigations, the mechanism of the therapeutic and prophylactic action of lithium ions $\left(\mathrm{Li}^{+}\right)$in manic-depressive disorder is still unclear. Besides a possible action on neurotransmitter metabolism and receptor sites, there are several indications that $\mathrm{Li}^{+}$might interact with the distribution and transport of potassium and sodium in the central nervous system. It has been reported in this context, that $\mathrm{Li}^{+}$induces a decrease in the $\mathrm{K}^{+}$concentration of brain slices ${ }^{19,42}$. Ullrich et al. ${ }^{40}$ described an elevation of the extracellular $\mathrm{K}^{+}$concentration in the cerebellum of rats which had been chronically treated with $\mathrm{Li}^{+}$. Furthermore, $\mathrm{Li}^{+}$inhibited the $\mathrm{K}^{+}$reuptake of brain cortical slices after a period of anaerobic incubation ${ }^{17}$ and also the $\mathrm{K}^{+}$uptake into astrocytes in primary cultures ${ }^{41}$. Complementary to these observations is the well-known interaction of $\mathrm{Li}^{+}$ with the electrogenic $\mathrm{Na}^{+} / \mathrm{K}^{+}$pump, as judged from the $\mathrm{Li}^{+}$-induced decrease or blockade of a membrane hyperpolarization following repetitive neuronal ac- tivity in rat or rabbit vagus nerve ${ }^{6,30.33}$, in amphibian optic nerve ${ }^{36}$, in the crayfish stretch receptor ${ }^{24}$ and in primary afferents of the frog spinal cord 5 . The latter effect has been investigated mainly using rather high concentrations of $\mathrm{Li}^{+}$, but it was also observed in the therapeutic concentration range ${ }^{6}$.

We have now extended the studies concerning $\mathrm{Li}^{+}$ and the $\mathrm{Na}^{+} / \mathrm{K}^{+}$pump by a comparative analysis of the effects of $\mathrm{Li}^{+}$on 3 different regions of the vertebrate CNS maintained in vitro. It has been investigated how $\mathrm{Li}^{+}$influences the membrane potential, membrane resistance, action potentials and synaptic potentials of neurons and glial cells in the isolated frog spinal cord, guinea pig olfactory cortex and hippocampus. Many of the experiments were performed using $\mathrm{K}^{+}$-sensitive microelectrodes parallel to conventional intra- or extracellularly located microelectrodes. Furthermore, dynamic changes of the extracellular $\mathrm{K}^{+}$concentration and of the membrane potential of neurons and glial cells have been observed under the influence of $\mathrm{Li}^{+}$. A special effort was made to determine the threshold for the actions of $\mathrm{Li}^{+}$on 
the parameters mentioned above. A preliminary publication of part of the results has already been published ${ }^{12}$.

\section{MATERIALS AND METHODS}

\section{Frog spinal cord}

Experiments were performed on Rana esculenta with the techniques described in detail elsewhere ${ }^{34}$. After decapitation, a ventral laminectomy was performed in cooled Ringer solution. The spinal cord, including dorsal and ventral roots of the lumbar segments, was removed and placed in a recording chamber (vol. $1.5 \mathrm{ml}$ ), which was continuously superfused with Ringer solution by means of a roller pump (2.5 $\mathrm{ml} / \mathrm{min})$. The Ringer solution contained (mmol/l): $\mathrm{NaCl}$ 98, $\mathrm{KCl} 3.6, \mathrm{CaCl} 2.0, \mathrm{NaHCO}_{3} 12$, glucose 10. The $\mathrm{pH}$ was continuously monitored and adjusted to 7.3-7.5 by varying the proportion of $\mathrm{O}_{2}$ and $\mathrm{CO}_{2}$ in the gassing mixture. The temperature of the perfusion fluid was adjusted to $18-21{ }^{\circ} \mathrm{C}$. The dorsal roots of the lumbar segments of one side were placed on silver wire electrodes for stimulation and covered with vaseline; the ventral roots of the same side were drawn into glass suction electrodes for stimulation or recording from the ventral roots. The construction and calibration of the double-barrelled ion-sensitive microelectrodes are described elsewhere ${ }^{13,14}$.

\section{Guinea pig olfactory cortex}

Male or female guinea pigs (about $300 \mathrm{~g}$ ) were decapitated and the brain was rapidly removed onto wet filter paper. Using a plastic guide and a bowcutter, a surface slice (approximately $500 \mu \mathrm{m}$ thick) of olfactory cortex was cut and placed in oxygenated Krebs solution at $30^{\circ} \mathrm{C}$. Slices were then transferred to a small temperature-controlled Perspex bath, sandwiched between two nylon meshes and completely submerged. Oxygenated Krebs solution at $30{ }^{\circ} \mathrm{C}$ was pumped through the bath at $8-10 \mathrm{ml} / \mathrm{min}$. The Krebs solution contained (mmol/l): $\mathrm{NaCl} 118$, $\mathrm{KCl} 3.0, \mathrm{CaCl}_{2}$ 1.5, $\mathrm{NaHCO}_{3} 25, \mathrm{NaH}_{2} \mathrm{PO}_{4} 1.2$, $\mathrm{MgCl}_{2}$ 1.0, glucose 10; this solution was continuously gassed with $95 \% \mathrm{O}_{2}-5 \% \mathrm{CO}_{2}, \mathrm{pH}=7.4$. Stimulation of the lateral olfactory tract (LOT), intracellular recording with $4 \mathrm{~mol} / \mathrm{l}$ potassium acetate-filled microelectrodes and extracellular recording with $\mathrm{K}^{+}$-sensi- tive microelectrodes were performed using conventional methods previously described8.

\section{Guinea pig hippocampus}

Procedures used in the preparation, maintenance and fixation of slices from the guinea pig hippocampus were in general accordance to the techniques described in detail by Lee et al. ${ }^{22}$. The medium which was continuously pumped through the recording chamber (flow rate $1-2 \mathrm{ml} / \mathrm{min}$; volume of the chamber $1.5 \mathrm{ml}$ ) was temperature-controlled at $35^{\circ} \mathrm{C}$ and contained (mmol/l): $\mathrm{NaCl} 124, \mathrm{KCl} 2.25, \mathrm{KH}_{2} \mathrm{PO}_{4}$ 1.25, $\mathrm{MgSO}_{4} 2.4, \mathrm{CaCl}_{2} 2.5, \mathrm{NaHCO}_{3} 25.7$, glucose 10 ; the solution reached but did not cover the surface of the slices. $\mathrm{Li}^{+}$was added via the solution and reached the chamber $3.5 \mathrm{~min}$ after the onset of superfusion. Stimulation of Schaffer collaterals was achieved by a bipolar tungsten wire electrode (resistance: $10 \mathrm{k} \Omega$ at $1700 \mathrm{~Hz}$ ) positioned in the stratum radiatum of the $\mathrm{CA} 3$ region. Recordings were made from the $\mathrm{CA} 1$ region by two micropipettes (filled
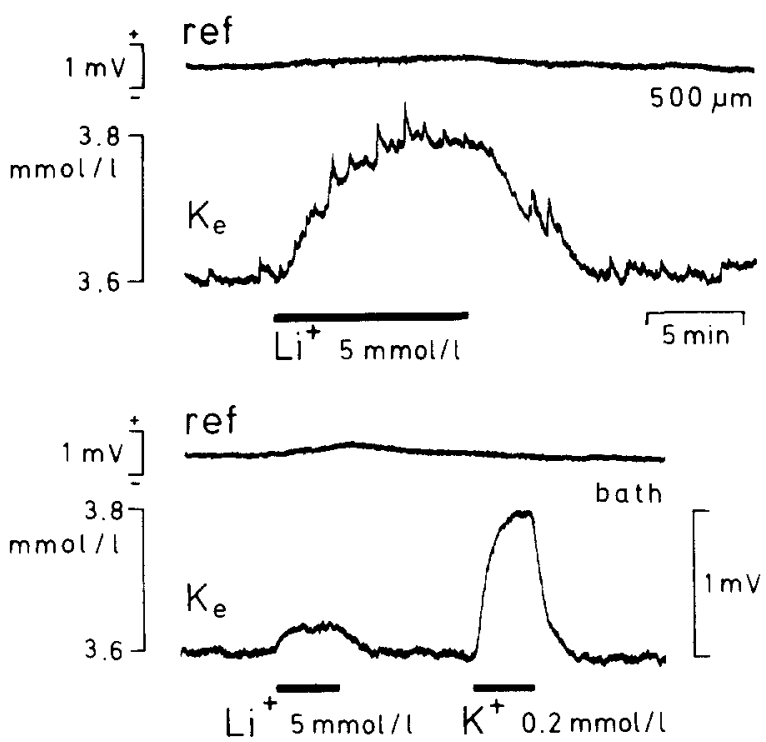

Fig. 1. Changes of extracellular potassium concentration $\left(\left[\mathrm{K}^{+}\right]_{\mathrm{e}}\right)$ in the isolated frog spinal cord during the application of $\mathrm{Li}^{+}$. The upper two traces show recordings of a $\mathrm{K}^{+}$-ion-sensitive microelectrode (ISME) at a depth of $500 \mu \mathrm{m}$ below the lateral surface of the spinal cord. The small fluctuations in the $\mathrm{K}_{\mathrm{e}}-$ trace are due to spontaneous synaptic activity (compare with Fig. 2A). The lower traces show measurements with the same $\mathrm{K}^{+}$-ISME after its withdrawal to the Ringer solution in the organ bath. $\mathrm{LiCl}(5 \mathrm{mmol} / \mathrm{l})$ and $\mathrm{KCl}(0.2 \mathrm{mmol} / \mathrm{l})$ have been added to the Ringer solution; the small change of the $\mathrm{K}_{\mathrm{e}}$-trace in the organ bath during the application of $\mathrm{Li}^{+}$is therefore due to a change in the ionic strength. 
with $2 \mathrm{M} \mathrm{NaCl}$, tip diameter $1.5-2 \mu \mathrm{m}$ ) placed at a depth of about $150 \mu \mathrm{m}$ below the surface of the slice in the soma and dendritic layer, respectively.

\section{RESULTS}

\section{Extracellular $\mathrm{K}^{+}$concentration}

The application of $\mathrm{LiCl}$ into the superfusion solution, either by exchanging it for an equimolar concentration of $\mathrm{NaCl}$, or by adding it to the normal saline, resulted in an elevation of the free extracellular $\mathrm{K}^{+}$concentration, $\left[\mathrm{K}^{+}\right]_{\mathrm{e}}$, in the isolated frog spinal cord (Figs. 1 and $2 \mathrm{~A}$ ) and in the guinea pig olfactory cortex (Fig. 2B). The rise in $\left[\mathrm{K}^{+}\right]_{\mathrm{c}}$ started within the first 2 min after $\mathrm{Li}^{+}$superfusion and a $\left[\mathrm{K}^{+}\right]_{e}$-peak was reached between 5 and 10 min later. During and after a long-lasting $\mathrm{Li}^{+}$-application, a slow decrease of $\left[\mathrm{K}^{+}\right]_{\mathrm{e}}$ to its baseline level, and an undershoot below the control values during the washing phase with normal saline, was observed. The threshold for this ef-
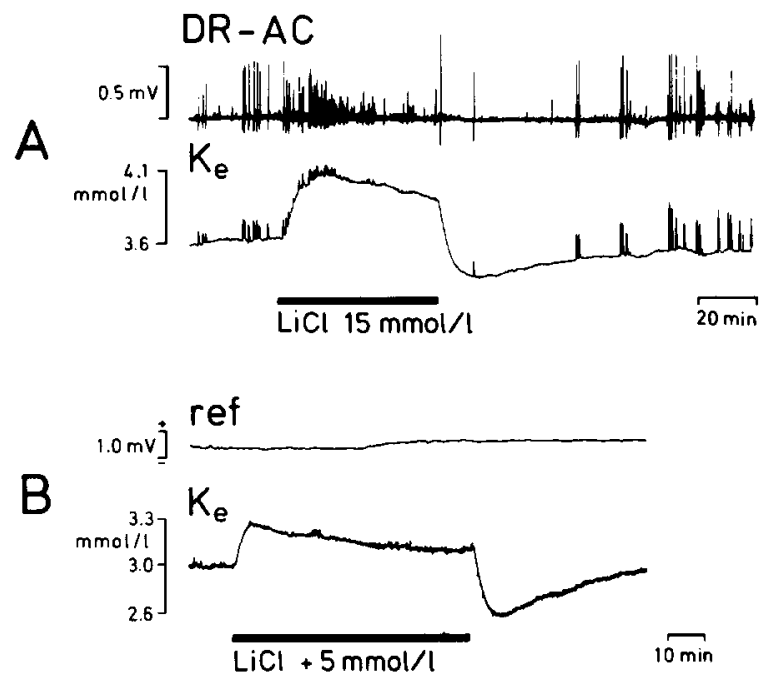

Fig. 2. A: effects of $\mathrm{Li}^{+}(15 \mathrm{mmol} / 1$, exchanged for $\mathrm{NaCl})$ on $\left[\mathrm{K}^{+}\right]_{e}$ and spontaneous synaptic activity in the frog spinal cord during a long-lasting application. The upper trace of $A$ shows the recording from a suction electrode containing one of the lumbar dorsal roots (DR; AC-coupled differential amplifier). The lower trace in $A$ illustrates alterations of $K_{e}$ during the same period and measured by a $\mathrm{K}^{+}$-ISME in the dorsal horn at a depth of $270 \mu \mathrm{m}$ below the lateral surface of the spinal cord. Note the increase of spontaneous activity in the dorsal root during the beginning of the $\mathrm{Li}^{+}$-superfusion and the absence of spontaneous activity during the post $\mathrm{Li}^{+} \mathrm{K}_{\mathrm{e}}$-undershoot. B: effects of $\mathrm{Li}^{+}\left(5 \mathrm{mmol} / 1\right.$ added to the Krebs solution) on $\left[\mathrm{K}^{+}\right]_{\mathrm{e}}$ in the olfactory cortex slice during a long lasting application. The $\mathrm{K}^{+}$-ISME was placed at a depth of about $300 \mu \mathrm{m}$ below the pia surface. Note also here the post $\mathrm{Li}^{+} \mathrm{K}_{\mathrm{e}}$-undershoot. fect was below $5 \mathrm{mmol} / \mathrm{l} \mathrm{LiCl}$ in the spinal cord and below $2 \mathrm{mmol} / \mathrm{l} \mathrm{LiCl}$ in the olfactory cortex. Quantitatively, in the isolated frog spinal cord at a depth of about $400-500 \mu \mathrm{m}$ below the lateral surface, a maximal increase of $\left[\mathrm{K}^{+}\right]_{\mathrm{e}}$ from 3.6 to $3.8 \pm 0.05 \mathrm{mmol} / \mathrm{l}$ (mean \pm S.D.; $\mathrm{n}=5$ ) during the administration of 5 $\mathrm{mmol} / 1 \mathrm{Li}^{+}$, and from 3.6 to $4.2 \pm 0.1 \mathrm{mmol} / \mathrm{l}(\mathrm{n}=10)$ during $15 \mathrm{mmol} / 1 \mathrm{Li}^{+}$, was measured. The given concentrations of $\mathrm{Li}^{+}$refer to the values in the organ bath; the real concentration of $\mathrm{Li}^{+} 15 \mathrm{~min}$ after application in deeper regions of the spinal cord is about $65 \%$ of that in the bathing solution, as demonstrated with $\mathrm{Li}^{+}$-sensitive microelectrodes ${ }^{13}$. In brain slices from the guinea pig olfactory cortex at a depth of about $200-300 \mu \mathrm{m}$ blow the pia, $\left[\mathrm{K}^{+}\right]_{\mathrm{c}}$ increased from 3.0 to $3.15 \pm 0.06 \mathrm{mmol} / \mathrm{l}$ (mean $\pm \mathrm{S} . \mathrm{D}$.; $\mathbf{n}=3 ; 2$ $\left.\mathrm{mmol} / \mathrm{L} \mathrm{Li}{ }^{+}\right)$, from 3.0 to $3.3 \pm 0.09 \mathrm{mmol} / \mathrm{l}(\mathrm{n}=13 ; 5$ $\left.\mathrm{mmol} / / \mathrm{Li}^{+}\right)$and from 3.0 to $3.9 \pm 0.3 \mathrm{mmol} / \mathrm{l}(\mathrm{n}=7$; $15 \mathrm{mmol} / \mathrm{Li}^{+}$).

Several experiments were performed to demonstrate that voltage changes measured by the $\mathrm{K}^{+}$-ionsensitive microelectrodes (ISME; Corning Ion Exchanger 477317) in the presence of $\mathrm{Li}^{+}$were indeed caused by an increase of $\left[\mathrm{K}^{+}\right]_{\mathrm{e}}$. Firstly, increases of $\left[\mathrm{K}^{+}\right]_{\mathrm{e}}$ observed with low concentrations of $\mathrm{Li}^{+}$added to the normal saline are not induced by an alteration of the ionic strength of the saline, since control measurements in the organ bath revealed much smaller voltage changes of the $\mathrm{K}^{+}-$ISME by application of $\mathrm{Li}^{+}$-containing solutions (Fig. 1). Moreover, in experiments with $15 \mathrm{mmol} / \mathrm{LiCl}$, the ionic strength of the solution was kept constant by exchanging $\mathrm{Li}^{+}$for an equimolar concentration of $\mathrm{NaCl}$. Secondly, identical changes of $\left[\mathrm{K}^{+}\right]_{e}$ were observed when either Corning $\mathrm{K}^{+}$-exchanger or valinomycin-based $\mathrm{K}^{+}$ISME were used. This fact indicates that the change of the ionic signal did not reflect an elevation of acetylcholine or other quaternary ammonium compounds in the spinal cord. Finally, 3 experiments were performed in the presence of TTX $(1 \mu \mathrm{mol} / 1)$. This resulted in only a small reduction of $\mathrm{Li}^{+}$-induced increases of $\left[\mathrm{K}^{+}\right]_{e}$, indicating that an indirect action of $\mathrm{Li}^{+}$on, for example, spontaneous synaptic activity is not the main reason for the elevation of $\left[\mathrm{K}^{+}\right]_{\mathrm{e}}$.

\section{$\left[\mathrm{K}^{+}\right]_{e^{-d e c a y ~}}$ phase after repetitive stimulation}

In addition to its effects on the $\left[\mathrm{K}^{+}\right]_{\mathrm{e}}$-baseline, $\mathrm{Li}^{+}$ also exhibited an influence on the $\left[\mathrm{K}^{+}\right]_{\mathrm{e}}$-decay phase 


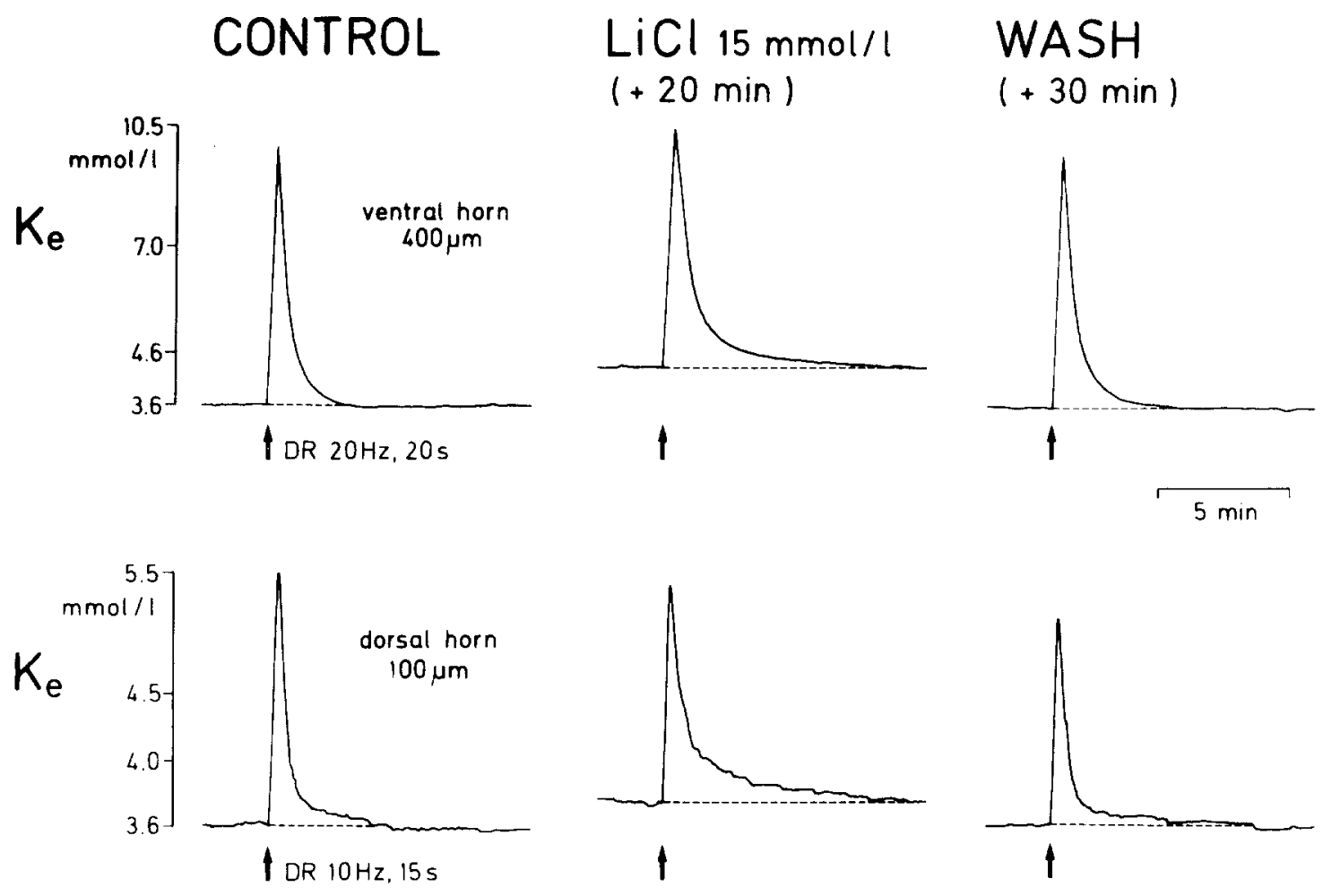

Fig. 3. Effects of $\mathrm{Li}^{+}$on the $\left[\mathrm{K}^{+}\right]_{\mathrm{e}}$-decay phase after repetitive stimulation of a dorsal root (DR) in the isolated frog spinal cord. The figure originates from two different experiments, in which $\mathrm{K}^{+}$-ISME have been used to measure the kinetics of $\mathrm{K}_{\mathrm{e}}$-changes during and after repetive stimulation of a dorsal root. The same stimulation parameters have been used before, during and after $\mathrm{Li}^{+}$-application $(15 \mathrm{mmol} / 1$, exchanged for $\mathrm{NaCl}$ ). The upper trace illustrates a recording in the ventral horn ( $400 \mu \mathrm{m}$ below the lateral surface) and the lower trace one in the dorsal horn $\left(100 \mu \mathrm{m}\right.$ below the lateral surface). Note the $\mathrm{Li}^{+}$-induced slowing of the $\left[\mathrm{K}^{+}\right]_{\mathrm{e}^{-}}$-decay phase.

after repetitive synaptic stimulation. In particular, this effect was observable in the isolated frog spinal cord. In normal Ringer's solution, repetitive stimulation of a dorsal root (stimulation parameters: 10-20 $\mathrm{Hz}, 10-20 \mathrm{~s}$ ) resulted in a $\left[\mathrm{K}^{+}\right]_{\mathrm{e}}$-elevation in the dorsal and ventral horn of the spinal cord. After the end of the stimulation, several minutes elapsed until $\left[\mathrm{K}^{+}\right]_{\mathrm{e}}$ had reached its resting baseline level (Fig. 3). A post-tetanic $\left[\mathrm{K}^{+}\right]_{\mathrm{e}}$-undershoot was not detected, in accordance with observations from other authors ${ }^{25.35}$. In the presence of $\mathrm{Li}^{+}$, a slowing of the $\left[\mathrm{K}^{+}\right]_{e}$-recovery phase was observed in both the ventral and the dorsal horns. The effects of $\mathrm{Li}^{+}$at a concentration of $5 \mathrm{mmol} / \mathrm{l}$ were weak, whereas clear changes were measured with $15 \mathrm{mmol} / \mathrm{L} \mathrm{LiCl}$ (12 experiments).

In the olfactory cortex slice, similar though less prominent effects of $\mathrm{Li}^{+}$on the $\left[\mathrm{K}^{+}\right]_{\mathrm{e}}$-decay phase after repetitive afferent stimulation $(20 \mathrm{~Hz}, 5-10 \mathrm{~s})$ were measured. Also in this preparation, a post-tet- anic $\left[\mathrm{K}^{+}\right]_{\mathrm{e}}$-undershoot did not occur. $\mathrm{Li}^{+}$, at a concentration of $5 \mathrm{mmol} / \mathrm{l}$, induced a slowing of the $\left[\mathrm{K}^{+}\right]_{\mathrm{e}}$-recovery phase in 4 out of 6 experiments (see Fig. 8).

\section{Membrane potential, membrane resistance and action} potentials

$\mathrm{Li}^{+}$induced a membrane depolarization in frog spinal motoneurons and in neurons of the guinea pig olfactory cortex. The depolarizations, however, were more pronounced in the latter preparation. Spinal motoneurons of the frog did not show a clear change of the resting membrane potential at 5 $\mathrm{mmol} / 1$, whereas $15 \mathrm{mmol} / 1 \mathrm{LiCl}$ produced a depolarization of $3.2 \pm 1.2 \mathrm{mV}$ (mean \pm S.D.; $\mathrm{n}=15$; see Figs. 4 and 5). $\mathrm{Li}^{+}$had a fast onset of action and recovery from the $\mathrm{Li}^{+}$-induced membrane depolarization was observed within a few minutes after washing with normal Ringer solution. A change in the input resistance of frog motoneurons was not observed 


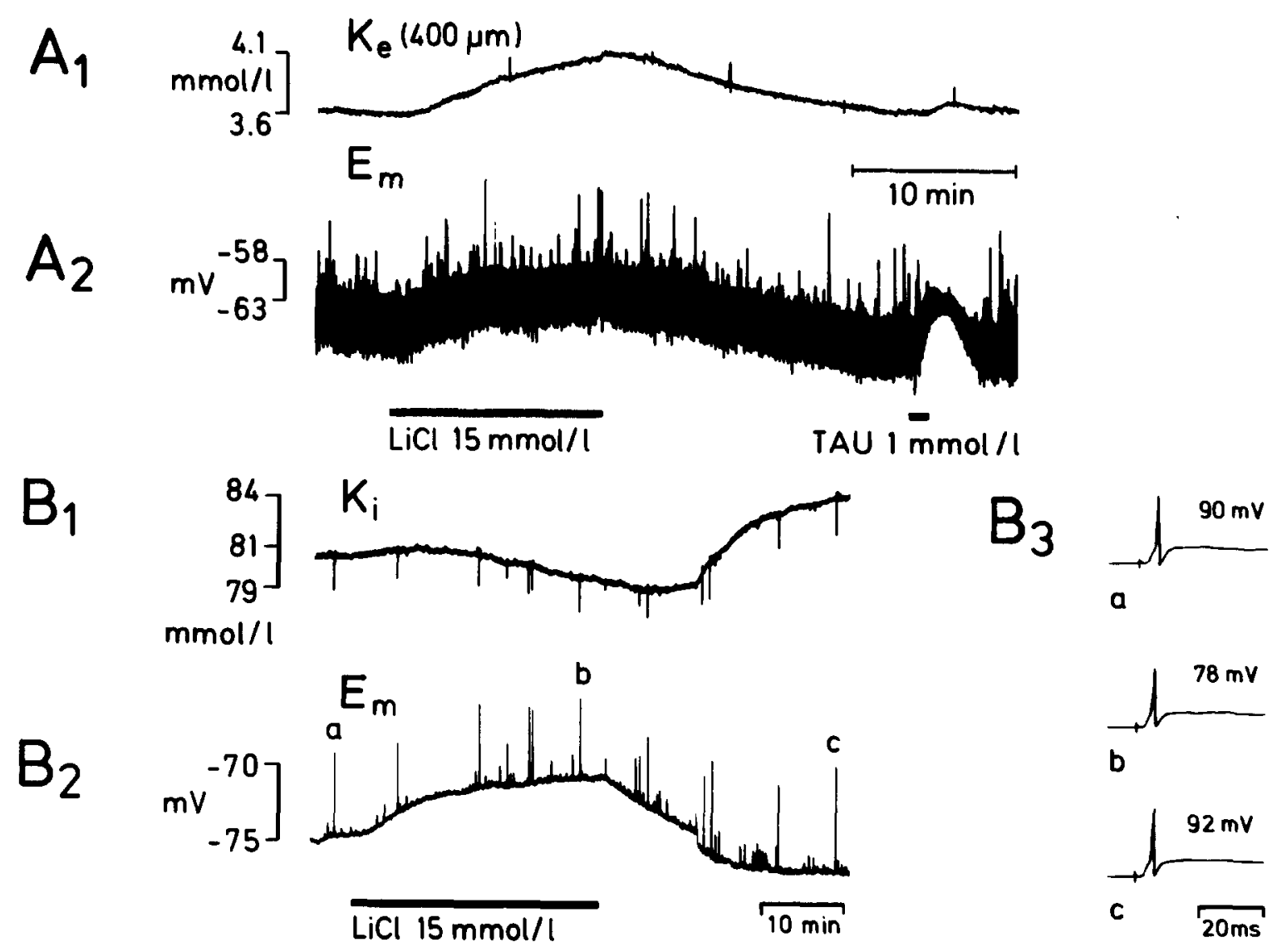

Fig. 4. Effects of $\mathrm{Li}^{+}$on membrane potential, membrane resistance, action potential amplitude and extra- and intracellular $\mathrm{K}^{+}$-concentrations of frog spinal motoneurons. $A_{1}$ shows the recording of a $K^{+-}$-ISME at a depth of $400 \mu \mathrm{m}$ below the lateral surface of the spinal cord. A conventional single-barrelled microelectrode was positioned intracellularly in a motoneuron at the same time $\left(\mathrm{A}_{2}\right)$. The deflections in the membrane potential trace $\left(E_{n}\right)$ consist of hyperpolarizing constant current pulses (duration $100 \mathrm{~ms}$; current $10 \mathrm{nA}$; frequency $0.2 \mathrm{~Hz}$ ) and depolarizing voltage deflections, which represent spontaneous synaptic activity. Application of LiCl (15 $\mathrm{mmol} / 1$, exchanged for $\mathrm{NaCl})$ induced an increase of $\left[\mathrm{K}^{+}\right]_{\mathrm{e}}$ and a depolarization of the motoneuron membrane without changing the input resistance. As a control, later on taurine (TAU) was applied into the superfusion solution which induced a typical decrease of the input resistance. B: impalement of a motoneuron with a double-barrelled $\mathrm{K}^{+}$-ISME. Determination of changes of the free intracellular $\mathrm{K}^{+}$-concentration $\left(\mathrm{B}_{1}\right)$ simultaneous to changes of the membrane potential $\left(\mathrm{B}_{2}\right)$ during the action of $\mathrm{Li}^{+}$. Amplitudes of synaptically induced action potentials compared before, during and after $\mathrm{Li}^{+}$in $\mathrm{B}_{3}$.

(Fig. 4). In olfactory cortex neurons, a clear membrane depolarization was detected. This depolarization was concentration-dependent and ranged between 2.5 and $5 \mathrm{mV}$ at $5 \mathrm{mmol} / 1 \mathrm{Li}^{+},(\mathrm{n}=5)$, and between 6 and $8 \mathrm{mV}$ at $15 \mathrm{mmol} / / \mathrm{Li}^{+}(\mathrm{n}=3)$. Again, no change in the input resistance of the neurons was observed (measured with constant hyperpolarizing current steps). It should be mentioned that the $\mathrm{Li}^{+}$-induced membrane depolarization was most prominent in neurons with high resting membrane potentials $(>-70 \mathrm{mV}$; see Figs. 6 and 7 ).

We have also investigated how $\mathrm{Li}^{+}$influences the membrane potential kinetics (of neurons in the frog spinal cord and guinea pig olfactory cortex) after repetitive synaptic stimulation. In the spinal cord, a post-tetanic membrane hyperpolarization of motoneurons was typically observed after repetitive stimulation of a dorsal root $(10-20 \mathrm{~Hz} ; 10-20 \mathrm{~s})$. It is very likely, that this hyperpolarization results from the activation of an electrogenic $\mathrm{Na}^{+} / \mathrm{K}^{+}$pump ${ }^{4,5,14,25}$. As illustrated in Fig. $5,15 \mathrm{mmol} / 1 \mathrm{LiCl}$ reduced or even abolished this post-tetanic membrane hyperpolarization. In addition, there was a membrane depolarization and an increase of spontaneous synaptic potentials. Also in the olfactory cortex, $\mathrm{a} \mathrm{Li}^{+}$-induced change in the post-tetanic behaviour of neurons was found. 


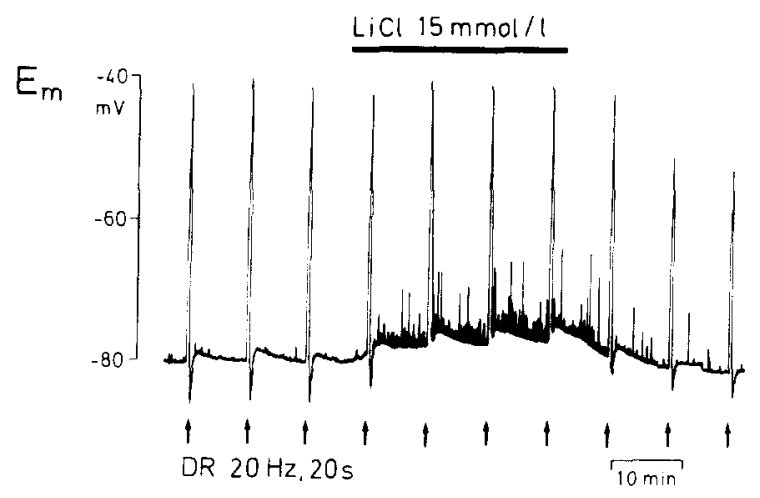

Fig. 5. Effects of $\mathrm{Li}^{+}$on the post-tetanic membrane hyperpolarization in a frog spinal motoneuron. A dorsal root was stimulated repetitively (frequency $20 \mathrm{~Hz}$; duration $20 \mathrm{~s}$ ) in regular intervals of about $8 \mathrm{~min}$ (indicated by arrows). The post-tetanic membrane hyperpolarization observable in normal Ringer solution was completely abolished in the presence of $\mathrm{Li}^{+}(15$ $\mathrm{mmol} / \mathrm{l}$, exchanged for $\mathrm{NaCl}$ ). Simultaneously, a membrane depolarization and an increase of spontaneous synaptic activity was observed.
However, in contrast to the uniform appearance of a post-tetanic hyperpolarization in frog motoneurons, more variable post-tetanic recovery phases were observed in olfactory cortex neurons. Sometimes, the membrane potential exhibited a long-lasting post-tetanic membrane depolarization whereas in other cases a membrane hyperpolarization was observed (stimulation of the lateral olfactory tract (LOT) with $10-30 \mathrm{~Hz} ; 5-10 \mathrm{~s}$ ). Additionally, and in contrast to the frog spinal motoneurons ${ }^{14}$, a clear change of the input resistance was seen during the post-tetanic recovery phase. Therefore, it is not possible, at the moment, to decide which mechanism is mainly responsible for the post-tetanic membrane behaviour of cortical neurons. Neurons with high membrane potentials ( -75 to $-85 \mathrm{mV}$ ), however, showed a typical longlasting post-tetanic membrane depolarization (see Figs. 6 and 7). In these cells, $\mathrm{Li}^{+}$induced a slowing of
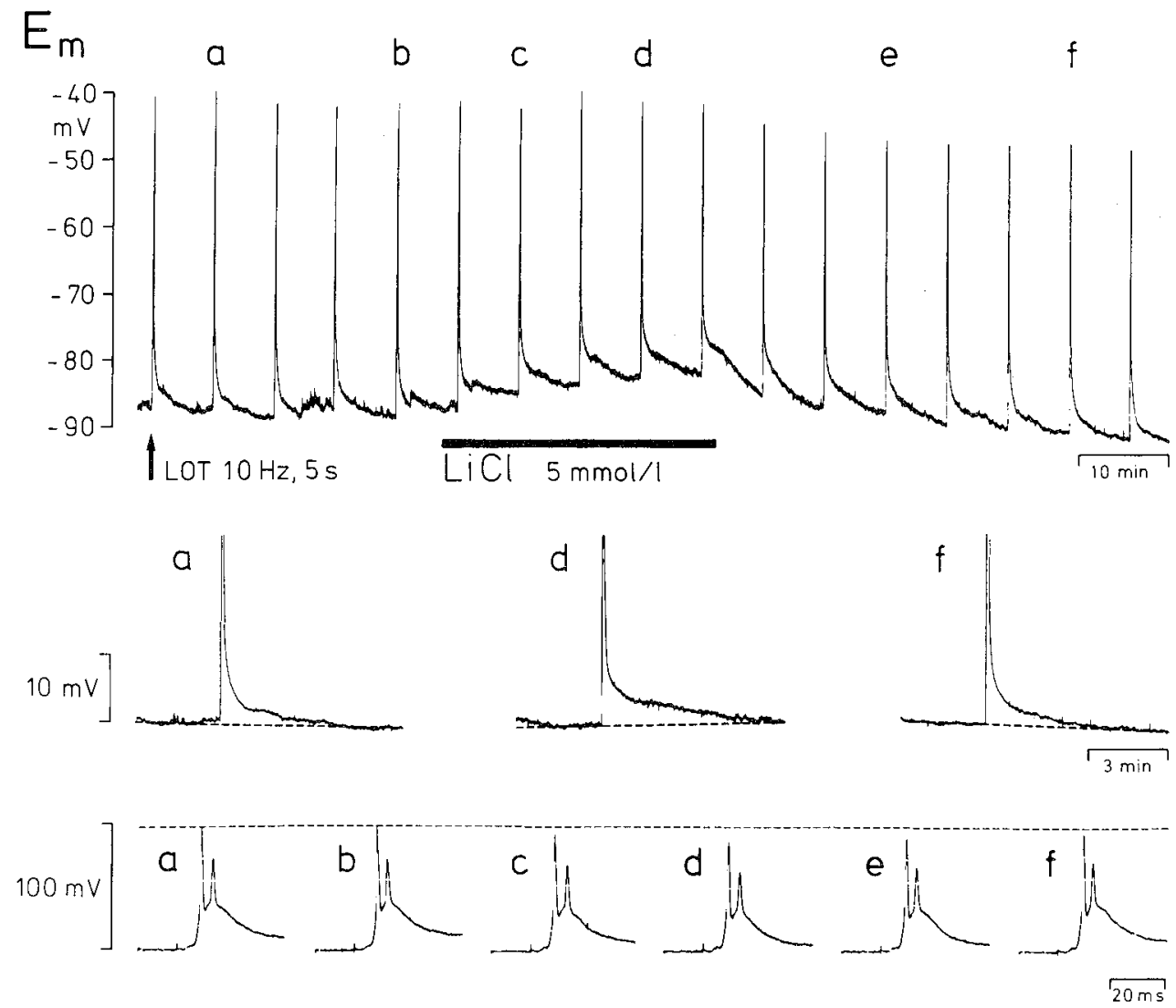

Fig. 6. Effects of $\mathrm{Li}^{+}$on a neuron of the guinea pig olfactory cortex slice. The uppermost trace shows the membrane potential of a cortical neuron with a slow time base. The lateral olfactory tract (LOT) has been stimulated repetitively (frequency $10 \mathrm{~Hz}$; duration $5 \mathrm{~s}$ ) in regular intervals of about $7 \mathrm{~min}$. During the period marked by the bar, $\mathrm{Li}^{+}(5 \mathrm{mmol} / \mathrm{l})$ was exchanged for an equimolar concentration of $\mathrm{NaCl}$ in the Krebs solution. The trace in the middle of the figure illustrates with a faster time base the post-tetanic membrane behaviour before (a), during (d), and after (f) application of $\mathrm{Li}^{+}$. The lowermost traces show action potentials evoked by the first shock of the trains and taken at the times indicated by the letters above the uppermost trace. Note, that $\mathrm{Li}^{+}$induced a decrease of the action potential amplitude. 
the post-tetanic membrane recovery $(5 \mathrm{mmol} / \mathrm{l})$. This effect of $\mathrm{Li}^{+}$was observed in addition to a membrane depolarization.

Also, it was investigated how $\mathrm{Li}^{+}$influences the amplitude of action potentials in spinal and cortical neurons. In the spinal cord, no change of the action potential amplitude was observed with $5 \mathrm{mmol} / \mathrm{Li}^{+}$ (see also ref. 13). However, $15 \mathrm{mmol} / \mathrm{l}$, a concentration that produced a membrane depolarization of the motoneurons, decreased the amplitude of synaptically induced action potentials. This effect is illustrated in Fig. 4B. The observation stems from one of the 3 experiments, in which the $\mathrm{Li}^{+}$-induced membrane depolarization was measured in motoneurons impaled with a double-barrelled $\mathrm{K}^{+}$-ISME. This enabled us to follow changes of the free intracellular $\mathrm{K}^{+}$-concentration $\left(\left[\mathrm{K}^{+}\right]_{i}\right)$ during the action of $\mathrm{Li}^{+}$. A small decrease in $\left[\mathrm{K}^{+}\right]_{i}$ was detected with a slow onset of action. The maximum decrease of $\left[\mathrm{K}^{+}\right]_{\mathrm{i}}$ in the 3 motoneurons, in which it was measured, ranged between 1 and $2.5 \mathrm{mmol} / 1 . \mathrm{A} \mathrm{Li}^{+}$-induced decrease in the amplitude of synaptically induced action potentials was also observed in neurons from the guinea pig olfactory cortex ( $5 \mathrm{mmol} / \mathrm{l}$; see Fig. 6 ).

\section{Glial cells}

In the following section, the effects of $\mathrm{Li}^{+}$on glial cell will be described. These investigations were performed on glial cells of olfactory cortex slices, because in this preparation glial cells were impaled rather frequently. The application of $\mathrm{Li}^{+}$resulted in a membrane depolarization and a slowing of the membrane potential recovery phase after repetitive stimulation of the LOT. The membrane depolarization started within the first $3 \mathrm{~min}$ of the onset of the $\mathrm{Li}^{+}$superfusion, and a maximum was reached 5-10 min later. The effect was reversed within a few minutes after the end of $\mathrm{Li}^{+}$-superfusion (see Fig. 8). Quantitatively, a membrane depolarization of $2.2 \pm 1 \mathrm{mV}$ (mean \pm S.D.; $\mathrm{n}=9$ ) during $5 \mathrm{mmol} / 1 \mathrm{Li}^{+}$(either added to the normal Krebs solution or exchanged for an equimolar concentration of $\mathrm{NaCl}$ ) was observed. However, these data only refer to measurements from glial cells at a depth of about $100-460 \mu \mathrm{m}$ below the pia surface of the brain slice. Very often glial cells just below the pia were impaled. In these cells, $\mathrm{a} \mathrm{Li}^{+}$. induced membrane depolarization $\left(5 \mathrm{mmol} / 1 \mathrm{Li}^{+}\right)$ was not detected. This fact is probably due to a lack of $\left[\mathrm{K}^{+}\right]_{\mathrm{e}}$ elevation in the superficial tissue layers which are in close contact to the fast-flowing bath solution. In the 3 glial cells on which $15 \mathrm{mmol} / \mathrm{LiCl}$ was tested, a membrane depolarization of about $5-7 \mathrm{mV}$ was observed. Furthermore, a dependence of the $\mathrm{Li}^{+}$-induced membrane depolarization on the resting membrane potentials of the glial cells was also observed. The amplitude of the depolarization was maximal at high resting potentials $(>-80 \mathrm{mV})$.

At the time of the membrane depolarization, a $\mathrm{Li}^{+}$-induced slowing of the membrane potential recovery phase of glial cells after repetitive stimulation
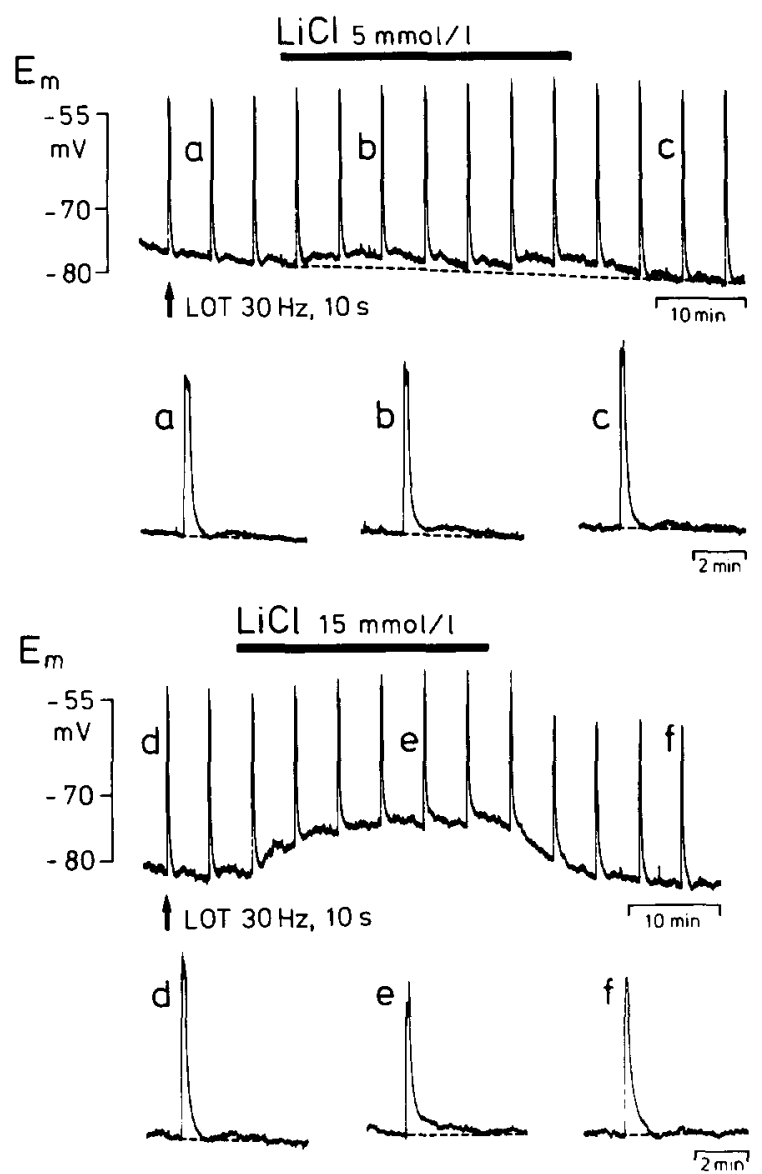

Fig. 7. Concentration-dependency of $\mathrm{Li}^{+}$-effects on a cortical neuron. The upper-most trace shows the membrane potential of a cortical neuron with a slow time base. The LOT has been stimulated repetitively (frequency $30 \mathrm{~Hz}$; duration $10 \mathrm{~s}$ ) in regular intervals of about $6 \mathrm{~min}$. During the period marked by the bar, $\mathrm{Li}^{+}(5 \mathrm{mmol} / \mathrm{l})$ was exchanged for an equimolar concentration of $\mathrm{NaCl}$ in the Krebs solution. The second trace from above illustrates the posttetanic membrane behaviour with a faster time base before (a), during (b), and after (c) application of $\mathrm{Li}^{+}$. The two lower traces show the same parameters during the application of $15 \mathrm{mmol} / \mathrm{Li}^{+}$(same neuron). 


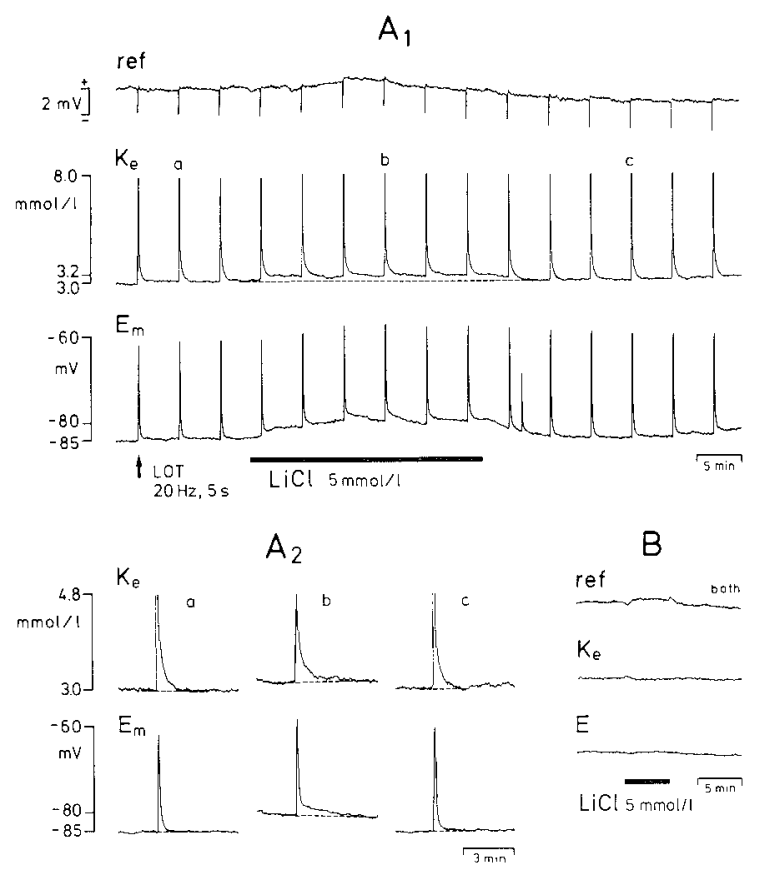

Fig. 8. Effects of $\mathrm{Li}^{+}$on a cortical glial cell. In this experiment, a simultaneous recording inside a glial cell $(270 \mu \mathrm{m}$ below surface, conventional electrode) and outside with a $\mathrm{K}^{+}$-ISME has been performed. The LOT has been stimulated repetitively (frequency $20 \mathrm{~Hz}$; duration $5 \mathrm{~s}$ ) in regular intervals. $\mathrm{A}_{\text {, illus- }}$ trates changes of $K_{c}$ and the glial cell membrane potential $\left(E_{m}\right)$ during the influence of $\mathrm{Li}^{+}(5 \mathrm{mmol} / \mathrm{l}$. exchanged for $\mathrm{NaCl}$ ) with a slow time base. $A_{2}$ shows the post-tetanic behaviour of $\mathrm{K}^{+}{ }_{c}$ and $\mathrm{E}_{\mathrm{m}}$ with faster time base and $\mathrm{B}$ illustrates recordings of the $\mathrm{K}^{+}$-ISME (ref.. $K_{c}$ ) and the single capillary $(E)$ after withdrawing of these electrodes into the Krebs solution of the organ bath.

of the LOT was also observed. A typical example is illustrated in Fig. 8. In this experiment a conventional microelectrode was used to record intracellularly from a glial cell ( $247 \mu \mathrm{m}$ below the pia) and an additional $\mathrm{K}^{+}$-ISME was used to measure the free extracellular $\mathrm{K}^{+}$concentration. Short stimulation trains were applied to the LOT at regular intervals. A display with a faster time base (Fig. $8 \mathrm{~A}_{2}$ ) reveals a $\mathrm{Li}^{+}$induced slowing of the post-tetanic behaviour of the glial cell membrane potential and the $\left[\mathrm{K}^{+}\right]_{\mathrm{c}}$-signal. Similar observations were made in 5 of the 7 experiments in which the action of $\mathrm{Li}^{+}(5 \mathrm{mmol} / \mathrm{l})$ on glial cells was investigated.

\section{$\mathrm{Li}^{+}$and synaptic potentials}

It has been shown that $\mathrm{Li}^{+}(15 \mathrm{mmol} / \mathrm{l})$ reduces the amplitudes of polysynaptic reflexes and increases the frequency of spontaneous synaptic activity in the iso- lated spinal cord of the frog 12 . Both effects could be imitated by an elevation of the extracellular potassium concentration from 3.6 to $4.6 \mathrm{mmol} / \mathrm{l}$. It is also known that $\mathrm{Li}^{+}(2-5 \mathrm{mmol} / \mathrm{l})$ is able to increase the amplitude of extracellularly recorded EPSP and synaptically evoked population spikes in brain slices from the rat hippocampus ${ }^{15}$. In order to support our hypothesis, that effects of $\mathrm{Li}^{+}$on the CNS are mainly due to an alteration of the potassium homeostasis leading to a membrane depolarization, we have now performed some experiments in which effects of $\mathrm{Li}^{+}$ and $\mathrm{K}^{+}$on field potentials of the hippocampus have

A

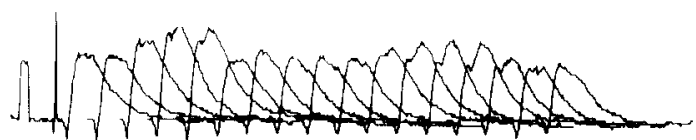

B
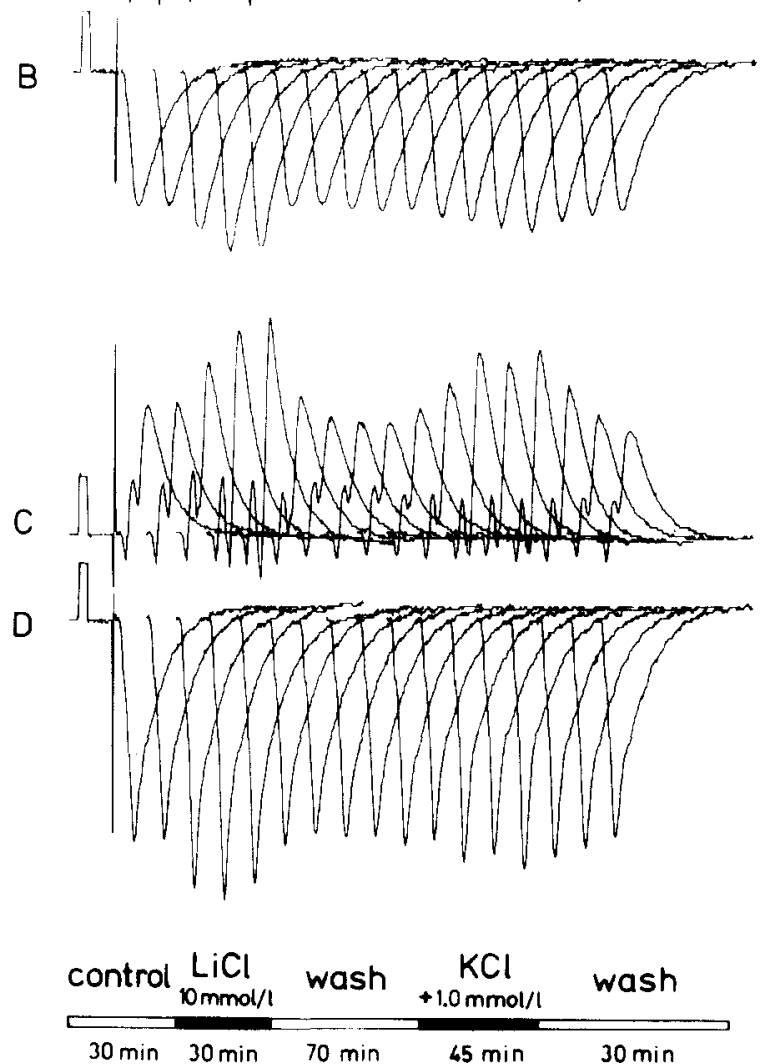

Fig. 9. Effects of $\mathrm{Li}^{+}$and $\mathrm{K}^{+}$upon evoked field potentials in the $C A_{1}$ region of a hippocampal slice. Traces $A$ and $C$ were recorded from the pyramidal cell layer, traces $B$ and $D$ from stratum radiatum. Potentials were evoked at a frequency of $0.2 \mathrm{~Hz}$ throughout the whole experiment. Measurements (4 sweeps averaged) were taken every 10 or 15 min during each experimental step using 5 different input intensities, two of which are plotted here: traces $\mathrm{A}$ and $\mathrm{B}$ were taken at $2.8 \mathrm{~V}$ and traces $\mathrm{C}$ and $\mathrm{D}$ at $4.55 \mathrm{~V}(90 \mu \mathrm{s}$ stimulation pulse $)$. 


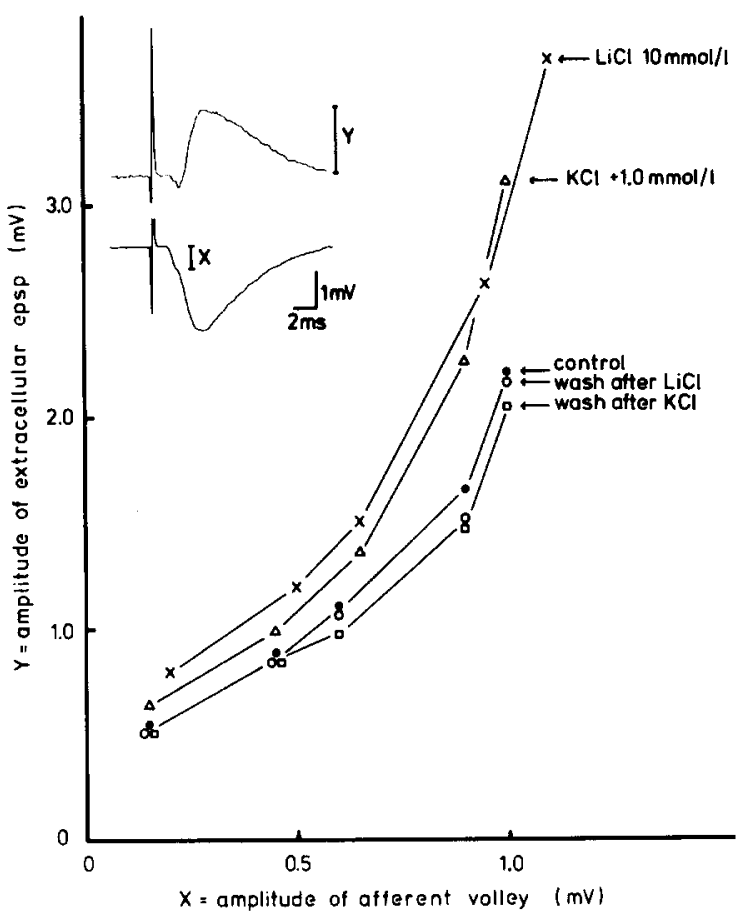

Fig. 10. Input-output graph of the effect of $\mathrm{Li}^{+}$and $\mathrm{K}^{+}$upon the extracellular EPSP. At 5 different stimulation intensities afferent volley amplitudes (abscissa) measured in the dendritic layer were correlated to the extracellular EPSP amplitudes (ordinate) measured in the somatic layer (see inset). The curves illustrate control values, values in the presence of $\mathrm{Li}^{+}$, during elevated $\mathrm{K}^{+}$(application time $20 \mathrm{~min}$ ) and values in the recovery periods ( 70 min after $\mathrm{Li}^{+}$and $30 \mathrm{~min}$ after $\mathrm{K}^{+}$). Data were taken from the experiment illustrated in Fig. 9.

been compared ( 8 brain slices from 8 guinea pigs). In these experiments $\mathrm{Li}^{+}$produced an increase in the amplitudes of evoked field potentials (Fig. 9). The action of $\mathrm{Li}^{+}$started 7-8 min after the onset of the $\mathrm{Li}^{+}$superfusion. Maximal values were reached after 20-30 min. Quantitatively, $5 \mathrm{mmol} / \mathrm{L} \mathrm{Li}^{+}$added to the normal saline increased the extracellular EPSP by 19 $\pm 8 \%$ (mean \pm S.D.) and the population spike by 61 $\pm 4 \% .10 \mathrm{mmol} / 1 \mathrm{Li}^{+}$exchanged for an equimolar concentration of $\mathrm{NaCl}$ in the saline caused an increase of $46 \pm 8 \%$ of the extracellular EPSP and of $149 \pm 29 \%$ of the population spike. Furthermore, population spikes were already seen at lower stimulation intensities than in control solution (Fig. 9A). The amplitude of the afferent volleys was unchanged by $\mathrm{Li}^{+}$in 7 experiments. In the one experiment in which afferent volleys increased by $8 \pm 2 \%$, the increase of the EPSP amplitude was independent of the increase of the afferent volley as judged from an input-output correlation (Fig. 10).
The excitatory effects of $\mathrm{Li}^{+}$could be imitated by increasing the $\mathrm{K}^{+}$concentration in the superfusion fluid. An elevation from 3.5 to $4.5 \mathrm{mmol} / \mathrm{l}$ caused a maximal increase of the extracellularly recorded EPSP by $34 \pm 3 \%$, and of the population spikes by $148 \pm 33 \%$. Similar to the action of $\mathrm{Li}^{+}$, population spikes already appeared at lower stimulation intensities. Afferent volley amplitudes always remained unchanged. With respect to the time course, an increase of EPSP amplitude was first seen about $10 \mathrm{~min}$ after the start of the $\mathrm{K}^{+}$superfusion; a maximal change was reached at around $30 \mathrm{~min}$. Both $\mathrm{Li}^{+}$and $\mathrm{K}^{+}$effects upon field potentials in hippocampal slices were reversible. $\mathrm{K}^{+}$effects could be washed out within 15-20 min, whereas $\mathrm{Li}^{+}$effects took much longer to be completely reversed. During the washout phase after $\mathrm{Li}^{+}$, a transient decrease of the EPSP amplitude by $12 \pm 3 \%$ was seen and the control values were then reached after about 50 min of washing (Fig. 9C).

\section{DISCUSSION}

The effects of $\mathrm{Li}^{+}$on the electrical activity and potassium ion distribution of frog spinal cord, guinea pig olfactory cortex and hippocampus observed in our experiments seem to be mainly a consequence of an interaction of $\mathrm{Li}^{+}$with the transport function of the $\mathrm{Na}^{+} / \mathrm{K}^{+}$pump. We will therefore start the discussion with the possible mechanisms underlying this interference. $\mathrm{Li}^{+}$may have 3 sites of action on the $\mathrm{Na}^{+} / \mathrm{K}^{+}$pump. (a) $\mathrm{Li}^{+}$might compete with $\mathrm{K}^{+}$for a common extracellular binding site. This possibility is supported by the demonstration that the uptake of $\mathrm{Li}^{+}$into neurons of primary brain cell cultures ${ }^{18}$, neuroblastoma cells ${ }^{11}$, neuroblastoma/glioma hybrid cells ${ }^{29}$ and in brain slices ${ }^{42}$ depends on the extracellular $\mathrm{K}^{+}$concentration. Low $\left[\mathrm{K}^{+}\right]_{\mathrm{e}}$ facilitates, whereas high $\left[\mathrm{K}^{+}\right]_{\mathrm{e}}$ inhibits, the $\mathrm{Li}^{+}$-uptake. Ouabain reduced the uptake of $\mathrm{Li}^{+}$into human neuroblastoma cells by up to $50 \% 32$. Furthermore, $\mathrm{Li}^{+}$inhibited the $\mathrm{K}^{+}$ reuptake in brain cortical slices after a period of anaerobic incubation ${ }^{17}$ and also the $\mathrm{K}^{+}$uptake into astrocytes in primary cultures ${ }^{41}$. Finally, it is also known that $\mathrm{Li}^{+}$is able to substitute for $\mathrm{K}^{+}$in activating the transmembranal $\mathrm{Na}^{+}$transport ${ }^{33}$. (b) $\mathrm{Li}^{+}$-influx into the intracellular space of neurons may decrease the free intracellular $\mathrm{Na}^{+}$concentration and thereby result in a reduced stimulation of the $\mathrm{Na}^{+} / \mathrm{K}^{+}$ 
pump from the interior of the cell. In fact, a diminution of $\left[\mathrm{Na}^{+}\right]_{i}$ in the presence of high extracellular $\mathrm{Li}^{+}$ concentrations has been decribed in the crayfish stretch receptor ${ }^{9}$ and in neurons of the snail after the application of $40 \mathrm{mmol} / 1 \mathrm{Li}^{+}$(ref. 27) and even with 1 $\mathrm{mmol} / / \mathrm{Li}^{+}$(ref. 1). The decrease of $\left[\mathrm{Na}^{+}\right]_{i}$ may show up quite rapidly, since $\mathrm{Li}^{+}$is able to enter neurons within $1 \mathrm{~min}$ after reaching the extracellular membrane surface, as has been measured with $\mathrm{Li}^{+}$-ISME in snail neurons ${ }^{38}$ and frog motoneurons ${ }^{13}$. The time course of the $\mathrm{Li}^{+}$-induced membrane depolarization is therefore consistent with an intracellular site of action of $\mathrm{Li}^{+}$. Evidence that $\mathrm{Li}^{+}$does not activate the $\mathrm{Na}^{+}$-site of the $\mathrm{Na}^{+} / \mathrm{K}^{+}$pump has been obtained by Thomas ${ }^{37}$ using direct injections of $\mathrm{Li}^{+}$-ions into snail neurons. (c) A third possibility is that $\mathrm{Li}^{+}$may change the electrogenic $\mathrm{Na}^{+} / \mathrm{K}^{+}$pump mode to an electroneutral $\mathrm{K}^{+/ \mathrm{K}^{+}}$pump mode, as suggested by Duhm ${ }^{7} \cdot \mathrm{K}^{+} / \mathrm{K}^{+}$exchange is activated by a lowering of $\left[\mathrm{Na}^{+}\right]_{i}$ and by inorganic phosphate, the concentration of which can rise substantially in nerve tissue upon repetitive stimulation ${ }^{31}$. Under these circumstances, $\mathrm{Li}^{+}$would be able to replace external $\mathrm{K}^{+}$in the $\mathrm{K}^{+} / \mathrm{K}^{+}$exchange mode. All the 3 sites of action just mentioned might contribute to the interaction of $\mathrm{Li}^{+}$with the transport function of the $\mathrm{Na}^{+} / \mathrm{K}^{+}$pump. Keeping in view such possible mechanisms, the following discussion will be devoted to the actions of $\mathrm{Li}^{+}$on electrical activity and on potassium ion distribution in the CNS.

One of the effects, which was consistently observed during $\mathrm{Li}^{+}$-application, was a depolarization of neurons in the frog spinal cord and guinea pig olfactory cortex. A membrane depolarization after a complete exchange of $\mathrm{Li}^{+}$against $\mathrm{Na}^{+}$has been also described on crayfish stretch receptors ${ }^{9.26}$ and on bullfrog ganglion cells ${ }^{20}$. In brain slices of rat hippocampus even low levels of $\mathrm{Li}^{+}(2-5 \mathrm{mmol} / \mathrm{l})$ caused a remarkable depolarization of CA1 pyramidal cells ${ }^{15}$. It has been suggested that the mechanisms underlying the $\mathrm{Li}^{+}$-induced membrane depolarization might be the reduced activity of an electrogenic sodium pump ${ }^{15.26}$, a decrease of the intracellular potassium concentration 9.20 and also part of it an increase of excitatory transmitter release ${ }^{15}$. Our data showing an increase of $\left[\mathrm{K}^{+}\right]_{c}$ and a decrease of $\left[\mathrm{K}^{+}\right]_{i}$ clearly demonstrate $\mathrm{a} \mathrm{Li}^{+}$-induced shift of the $\mathrm{K}^{+}$equilibrium potential towards more depolarized levels. This ac- tion of $\mathrm{Li}^{+}$seems to be the main reason for the membrane depolarization of the neurons. The lack of a change of the membrane resistance and the depolarization of glial cells is in support of this view. A reduced activity of the electrogenic sodium pump, however, cannot be excluded because our measurements with $\mathrm{K}^{+}$-ISME are not accurate enough to determine the potassium distribution exactly at the membrane surface of the neurons. This information is necessary to allow us to calculate whether the shift of the $\mathrm{K}^{+}$ equilibrium potential alone is sufficient to account for the membrane depolarization. The basic mechanism leading to the shift of the $\mathrm{K}+$ equilibrium potential, however, might be an interaction of $\mathrm{Li}^{+}$with the transport function of the $\mathrm{Na}^{+} / \mathrm{K}^{+}$pump (see first paragraph of Discussion).

A depolarization of the postsynaptic membrane is also the most likely mechanism underlying the increase of population spikes seen in the presence of $\mathrm{Li}^{+}$. The population spike is a function of the number of discharging cells. Thus, during a $\mathrm{Li}^{+}$-induced membrane depolarization the number of cells from which a given input intensity elicits action potentials will increase. This view is strongly supported by the finding that increases in population spikes very similar to those seen in the presence of $\mathrm{Li}^{+}$were elicited by an elevation of $\left[\mathrm{K}^{+}\right]_{e}$. The facilitation of the EPSP amplitude, on the other hand, probably results from an action on the presynaptic terminal. $\mathrm{Li}^{+}$might induce a depolarization of the presynaptic membrane or a change in the free intracellular $\mathrm{Ca}^{2}+$ concentration in analogy to its effect on snail neurons ${ }^{1}$. However, the similarity in the action of $\mathrm{K}^{+}$and $\mathrm{Li}^{+}$might indicate that a depolarization of the nerve terminal is the main mechanism underlying the facilitation of the EPSP amplitude.

$\mathrm{Li}^{+}$induced a slowing of the post-tetanic $\left[\mathrm{K}^{+}\right]_{\mathrm{c}}$ recovery phase to the resting value. This observation in the isolated spinal cord of the frog and guinea pig olfactory cortex resembles the reduction in the poststimulus $\left[\left.\mathrm{K}^{+}\right|_{\mathrm{e}}\right.$-undershoot measured in isolated rat sympathetic ganglia ${ }^{3}$ and in the rat cerebellum ${ }^{40}$ during acute or chronic application of $\mathrm{Li}^{+}$. It is wellknown that the $\mathrm{Na}^{+} / \mathrm{K}^{+}$pump is an important factor determining the decay of $\mathrm{K}^{+}$potentials in the central nervous system ${ }^{21}$. Consequently, any impairment of the transport function of the $\mathrm{Na}^{+} / \mathrm{K}^{+}$pump by $\mathrm{Li}^{+}$ should cause a slowing of the post-tetanic $\left[\mathrm{K}^{+}\right]_{\mathrm{c}}$ re- 
covery phase, as has been observed also in the present experiments. $\mathrm{Li}^{+}$additionally induced a reduction in the amplitude of membrane hyperpolarization occurring in frog spinal motoneurons after repetitive stimulation of a dorsal root. It has been demonstrated that this hyperpolarization results from the activation of an electrogenic $\mathrm{Na}^{+}$pump $p^{4,5,14,25}$. The reduction of the hyperpolarization in the presence of $\mathrm{Li}^{+}$is therefore also consistent with an impairment of the $\mathrm{Na}^{+} / \mathrm{K}^{+}$pump.

Without appropriate measurements it remains unclear whether the effects of $\mathrm{Li}^{+}$observed in our in vitro experiments are involved in the therapeutic action of $\mathrm{Li}^{+}$in man. Usually, no significant changes of the serum ${ }^{16.23}$ and $\mathrm{CSF}^{28} \mathrm{~K}^{+}$-concentration during $\mathrm{Li}^{+}$-therapy have been found. However, changes in serum $\left[\mathrm{K}^{+}\right]$are not likely to appear, since the adrenal-renal regulatory mechanisms would correct any deviation from homeostatic norm. Even a patient suffering from $\mathrm{Li}^{+}$-intoxication (serum $\mathrm{Li}^{+}$concentration $3.8 \mathrm{mmol} / \mathrm{l}$ ) did not show a serum $\mathrm{K}^{+}$concentration outside the normal range ${ }^{2}$, although a $\mathrm{Li}^{+}$-induced hyperkalemia $(6.2 \mathrm{mmol} / \mathrm{l})$ has been reported as well ${ }^{10}$. On the other hand, measurements of the extracellular $\mathrm{K}^{+}$-concentration alone do not describe the transmembranal $\mathrm{K}^{+}$-gradient, i.e. the $\mathrm{K}^{+}$-equi-

\section{REFERENCES}

1 Aldenhoff, J. B. and Lux, H. D., Effect of lithium on calcium-dependent membrane properties and on intracellular calcium-concentration in helix neurons. In H. M. Emrich, J. B. Aldenhoff and H. D. Lux (Eds.), Basic Mechanisms in the Action of Lithium, Excerpta Medica, 1982, pp. 50-63.

2 Askenasi, R., Linkowski, P. and Leeman, M., Seizure due to lithium intoxication, Nouv. Presse Med., 10 (1981) 3481-3483

3 Bruggencate, G. ten, Ullrich, A., Galvan, M., Förstl, H. and Baierl, P., Effects of lithium application upon extracellular potassium in structures of the peripheral and central nervous system of rats. In D. W. Lübbers et al. (Eds.), Progress in Enzyme and Ion-Selective Electrodes, SpringerVerlag, Berlin, 1981, pp. 135-140.

4 Czeh, G., Křǐž, N. and Syková, E., Extracellular potassium accumulation in the frog spinal cord induced by stimulation of the skin and ventrolateral columns, J. Physiol. (Lond.), 320 (1981) 57-72.

5 Davidoff, R. A. and Hackman, J. C., Hyperpolarization of frog primary afferent fibers caused by activation of a sodium pump, J. Physiol. (Lond.), 302 (1980) 297-309.

6 Den Hertog, A. and Ploeger, E. J., Mechanism of action of lithium salts, Psychiat. Neurol. Neurochir., 76 (1973) 529-535.

7 Duhm, J., Note on the interaction of lithium ions with the librium potential. However, the cardiotoxicity of $\mathrm{Li}^{+}$ in humans (depression, sometimes inversion, of the T-wave in the electrocardiogram ${ }^{39}$ ) has been postulated to reflect an intracellular myocardial $\mathrm{K}^{+}$-depletion. If a similar depletion of intracellular $\left[\mathrm{K}^{+}\right]$occurs in the brain of patients, it may play a part either in the therapeutic action of $\mathrm{Li}^{+}$, or in its toxic effects, or both. In addition, effects of $\mathrm{Li}^{+}$on the kinetics of dynamic changes of $\left[\mathrm{K}^{+}\right]$during phasic neuronal activity have also been observed in our investigation. It may be, therefore, that effects of $\mathrm{Li}^{+}$on the kinetics of the membrane potential of neurons and glial cells after repetitive synaptic stimulation are also important for its therapeutic action. At present, however, there is no possibility to determine whether such an effect of $\mathrm{Li}^{+}$occurs in the brain of the patients.

\section{ACKNOWLEDGEMENTS}

We would like to thank Dr. J. Rimpel and Ms. C. Koestler for participation in several of the frog spinal cord experiments and Dr. A. Barber for correcting the English. Expert technical assistance was given by Mrs. C. Müller, Ms. G. Schneider and Mrs. E. Henoch. The work was supported by a grant given by the Wilhelm Sander Stiftung.

transport function of the $\mathrm{Na}^{+}-\mathrm{K}^{+}$-pump. In H. M. Emrich, J. B. Aldenhoff and H. D. Lux (Eds.), Basic Mechanisms in the Action of Lithium, Excerpta Medica, 1982, pp. 21-27.

8 Galvan, M., Grafe, P. and ten Bruggencate, G., Convulsant action of 4-aminopyridine on the guinea-pig olfactory cortex slice, Brain Research, 241 (1982) 75-86.

9 Giacobini, E., Hovmark, S. and Stepita-Klauco, M., Studies on the mechanism of action of lithium ions. II. Potassium sensitive influx of lithium ions into the crayfish stretch receptor neuron determined by microphlame photometry, Acta physiol. scand., 80 (1970) 528-532.

10 Goggans, F. C., Acute hyperkalemia during lithium treatment of manic illness, Amer. J. Psychiat., 137 (1980) $860-861$.

11 Gorkin, R. A. and Richelson, E., Lithium transport by mouse neuroblastoma cells, Neuropharmacology, 20 (1981) 791-801.

12 Grafe, P., Rimpel, J., Reddy, M. M., Koestler, C. and ten Bruggencate G., Effects of lithium on motoneurons, synaptic transmission and extracellular potassium in the isolated frog spinal cord. In H. M. Emrich, J. B. Aldenhoff, and H. D. Lux (Eds.), Basic Mechanisms in the Action of Lithium, Excerpta Medica, 1982, pp. 92-101.

13 Grafe, P., Rimpel, J., Reddy, M. M. and ten Bruggencate G., Lithium distribution across the membrane of motoneurons in the isolated frog spinal cord, Pflügers Arch. ges. Physiol., 393 (1982) 297-301. 
14 Grafe. P.. Rimpel, J. Reddy, M. M. and ten Bruggencate G. . Changes of intracellular sodium and potassium concentrations in frog spinal motoneurons induced by repetitive synaptic stimulation. Neuroscience, 7 (1982) 3213-3220.

15 Haas, H. L., Lithium and synaptic transmission in the mammalian brain. In H. M. Emrich. J. B. Aldenhoff and H. D. Lux (Eds.), Basic Mechanisms in the Action of Lithium, Excerpta Medica, 1982, pp. 71-79.

16 Hullin, R. P., The effects of lithium on electrolyte balance and body fluids. In F. N. Johnson (Ed.), Lithium Research and Therapy, Academic Press, 1975, pp. 359-380.

17 Israel, Y.. Kalant, H. and Le Blanc, A. E., Effects of lower alcohols on potassium transport and microsomal adenosine-triphosphatase activity of rat cerebral cortex. Biochem. J., 100 (1966) 27-33.

18 Janka, Z., Szentistvanyi. I. and Rimanoczy, R., The influence of external sodium and potassium on lithium uptake by primary brain cell cultures at 'therapeutic' lithium concentration. Psychopharmacology, 71 (1980) 159-165.

19 Kjeldsen, C. S., Lund-Andersen. H. and Hertz, L.. Effects of lithium ions in a pharmacological concentration on potassium and sodium ions in rat brain cortex slices. Biochem. Soc. Trans., 1 (1973) 111-114

20 Koketsu. K. and Yamamoto, K., Effects of lithium ions on electrical activity in sympathetic ganglia of the bullfrog. Brit J. Pharmacol., 50(1974) 69-77.

21 Krnjevic, K. and Morris, M. E., Factors determining the decay of $\mathrm{K}^{+}$-potentials and focal potentials in the central nervous system. Canad. J. Physiol. Pharmacol., 53 (1975) 923-934.

22 Lee, K.. Oliver. M., Schottler, F. and Lynch, G., Electron microscopic studies of brain slices: the effects of high-frequency stimulation on dendritic ultrastructure. In G. A. Kerkut and H. V. Wheal (Eds.). Electrophysiology of Isolated Mammalian CNS Preparations, Academic Press, 1981, pp. 189-211

23 Myers, J. B., Morgan, T. O., Carney, S. L. and Ray, C., Effects of lithium on the kidney. Kidney Int, 18 (1980) $601-608$.

24 Nakajima, S. and Takahashi, K.. Post-tetanic hyperpolarization and electrogenic $\mathrm{Na}^{+}$-pump in stretch receptor neurone of crayfish, J. Physiol. (Lond.), 187 (1966) 105-127.

25 Nicoll, R. A.. Dorsal root potentials and changes in extracellular potassium in the spinal cord of the frog, J. Physiol. (Lond.), 290 (1979) 113-127.

26 Obara, S. and Grundfest, H. . Effect of lithium on different membrane components of crayfish stretch receptor neurons, J. gen. Physiol., 51 (1968) 635-654.

27 Partridge, L. D. and Thomas. R. C. The effects of lithium and sodium on the potassium conductance of snail neurones, J. Physiol. (Lond.), 254 (1976) 551-563.

28 Paul, H. A., Pilz, H. and Munz, E., Der Lithiumgehalt im
Liquor cerebrospinalis bei Therapie mit Lithiumsalzen, Nervenarzt, 44 (1973) 210-211.

29 Reiser, G. and Duhm, J., Transport pathway for lithium ions in neuroblastoma $\times$ glioma hybrid cells at 'therapeutic' concentrations of $\mathrm{Li}^{+}$. Brain Research, 252 (1982) 247-258.

30 Ritchie, J. M. and Straub, R. W., The hyperpolarization which follows activity in mammalian non-medullated fibres, J. Physiol. (Lond.), 136 (1957) 80-97.

31 Ritchie, J. M. and Straub, R. W., Phosphate efflux and oxygen consumption in small non-myelinated nerve fibers at rest and during activity, J. Physiol. (Lond.), 287 (1979) 315-327.

32 Saneto, R. P., Srivastava, S. K., Werrbach-Perez, K. and Perez-Polo, J. R., Lithium uptake at physiological ion concentration in a human clonal neuroblastoma cell line, $J$. Neurochem., 34 (1980) 1523-1524.

33 Smith, I. C. H., The electrogenic potential in rat $\mathrm{C}$ nerve fibers: some effects of lithium and thallium, J. Physiol. (Lond.), 294 (1979) 135-144.

34 Sonnhof, U., Grafe, P., Krumnikl, J., Linder, M. and Schindler. L., Inhibitory postsynaptic actions of taurine, GABA and other amino acids on motoneurons of the isolated frog spinal cord, Brain Research, 100 (1975) 327-341.

35 Syková, E., Shirayev, B., Kříž, N. and Vyklický, L., Accumulation of extracellular potassium in the spinal cord of frog, Brain Research, 106 (1976) 413-417.

36 Tang, C. M., Cohen, M. W. and Orkand, R. K., Electrogenic pumps in axons and neuroglia and extracellular potassium homeostasis, Brain Research, 194 (1980) 283-286.

37 Thomas, R. C., Membrane current and intracellular sodium changes in a snail neurone during extrusion of injected sodium, J. Physiol. (Lond.), 201 (1969) 495-514.

38 Thomas, R. C., Simon, W. and Oehme, M., Lithium accumulation by snail neurones measured by a new $\mathrm{Li}^{+}$-sensitive microelectrode, Nature, (Lond.), 258 (1975) 754-756.

39 Tilkian, A. G., Schroeder, J. S. and Hultgren, H., Cardiotoxicity of lithium salts. In M. R. Bristow (Ed.), Drug-Induced Heart Disease, Elsevier/North-Holland Biomedical Press, 1980, pp. 293-303.

40 Ullrich, A., Baierl, P. and Bruggencate, G. ten, Extracellular potassium in rat cerebellar cortex during acute and chronic lithium application, Brain Research, 192 (1980) 287-290.

41 Walz, W. and Hertz, L., Acute and chronic effects of lithium in therapeutically relevant concentrations on potassium uptake into astrocytes, Psychopharmacology, 78 (1982) 309-313.

42 Wraae. O., Hillman. H. and Round, E., The uptake of low concentrations of lithium ions into rat cerebral cortex slices and its dependence on cations, $J$. Neurochem., 26 (1976) 835-843. 